\title{
MODEL PEMBELAJARAN PROJECT BASED LEARNING TERHADAP KEMAMPUAN PEMECAHAN MASALAH MATEMATIKA
}

\author{
MAYA NURFITRIYANTI \\ Program Studi Pendidikan Matematika, Fakultas Teknik Matematika dan IPA \\ Universitas Indraprasta PGRI
}

\begin{abstract}
The purpose of this study was to determine effect of learning model project based learning to mathematic problem solving skills. This study was a quantitative research by eksperiment method. This study was doing in 2015 at one Senior High Schools in Bekasi Timur. Samples of this study were 70 students. Statistic test of this study using t test. The result of this study was there are effect of learning model project based learning to mathematic problem solving skills by $\mathrm{t}$ count was 3,87 and $\mathrm{t}$ table was 1,67 .
\end{abstract}

Keyword : mathematic problem solving skills, learning model project based learning.

\section{PENDAHULUAN}

Peran pendidikan sangatlah penting, terutama untuk meningkatkan kualitas sumber daya manusia. Pendidikan harus mampu mencetak individu-individu yang mempunyai pengetahuan tinggi, daya kompetitif, kreativitas, dan sikap budi pekerti agar kualitas sumber daya manusia semakin meningkat. Hal ini sesuai dengan tujuan pendidikan yang tercantum dalam undang-undang. Amaliah (2012: 1) mengutip UndangUndang No. 20 tahun 2003 tentang Sisdiknas disebutkan bahwa: "Pendidikan nasional berupaya untuk mengembangkan kemampuan dan membentuk watak serta peradaban bangsa yang bermartabat dalam rangka mencerdaskan kehidupan bangsa, bertujuan untuk mengembangkan potensi agar menjadi manusia yang beriman dan bertakwa kepada Tuhan Yang Maha Esa, berakhlak mulia, sehat, berilmu, cakap, kreatif, mandiri, dan menjadi warga negara yang demokratis serta bertanggungjawab". Sehingga jika kualitas pendidikan rendah, maka tujuan pendidikan tidak akan tercapai dan mengakibatkan rendahnya penyediaan sumber daya manusia yang berkualitas.

Salah satu mata pelajaran yang berperan penting dalam pendidikan adalah matematika. Matematika merupakan ilmu universal yang mendasari perkembangan teknologi modern. Selain itu matematika mempunyai peran penting dalam disiplin ilmu pengetahuan dan mengembangkan daya pikir manusia. Pelajaran matematika merupakan pelajaran yang membutuhkan penalaran dan logika yang tinggi, sehingga dalam kegiatan pembelajaran matematika, peserta didik dituntut untuk cerdas, kreatif, terampil dan mandiri dalam memahami dan menerapkan konsep yang dipelajari.

Matematika merupakan simbol-simbol, kumpulan angka, serta operasi perhitungan konsep-konsep abstrak yang harus di pahami dan berkonsentrasi dalam pengerjaannya. Hal itulah yang membuat banyak peserta didik menganggap bahwa matematika adalah mata pelajaran yang sulit, membosankan dan menakutkan. Sehingga kreativitas pembelajaran matematika perlu dikembangkan, karena matematika harus diajarkan secara menarik dan terhubung dengan dunia nyata dan menggunakan variasi metode pembelajaran, dengan demikian tercipta suasana belajar yang menyenangkan.

Melihat kondisi diatas, guru perlu menciptakan lingkungan yang kondusif bagi para peserta didik dengan menggunakan model pembelajaran yang tepat. Model pembelajaran yang membosankan tidak akan terjadi proses mentransfer ilmu kepada peserta didik. Dengan menggunakan model pembelajaran yang tepat, peserta didik tidak 
hanya dituntut untuk mendengarkan dan menghafal materi yang diberikan oleh guru, tetapi peserta didik juga aktif dalam mencari materi yang akan dipelajarinya. Dengan demikian peserta didik terdorong untuk berfikir kreatif dan bertanggung jawab atas apa yang mereka pelajari. Selain itu, peserta didik juga dapat memecahkan masalah yang dihadapi baik yang berkaitan dengan sekolah maupun masalah yang terjadi dalam kehidupan masyarakat.

Berdasarkan pengamatan, banyak sekolah yang menggunakan model pembelajaran berpusat pada guru dalam mengajar matematika, artinya pembelajaran hanya terpaku pada apa yang disampaikan oleh guru. Aktifitas guru jauh lebih besar dibandingkan dengan aktifitas peserta didik. Selain itu, pembelajaran yang dilakukan kurang terkait dengan kehidupan sehari-hari peserta didik. Guru tidak memberikan pembelajaran yang bermakna karena peserta didik hanya mendengarkan, mencatat dan menghafal, sehingga peserta didik tidak aktif dan kreatif dalam memecahan masalah matematika yang mengakibatkan hasil belajar matematika yang dicapai rendah. Maka dari itu hendaknya guru dapat memilih dan menerapkan suatu model pembelajaran yang lebih efektif untuk disajikan sesuai dengan bentuk materi yang akan disampaikan dalam kemampuan pemecahan masalah matematika.

Salah satu model pembelajaran yang cocok dalam pembelajaran matematika yaitu project based learning. Menurut Bie (Ngalimun, 2013: 185) menegaskan project based learning yaitu: "model pembelajaran yang berfokus pada konsep-konsep dan prinsipprinsip utama (central) dari suatu disiplin, melibatkan siswa dalam kegiatan pemecahan masalah dan tugas-tugas bermakna lainnya, memberikan peluang siswa bekerja secara otonom mengkonstruk belajar mereka sendiri, dan puncaknya menghasilkan produk karya siswa bernilai, dan realistik". Model pembelajaran project based learning dapat menumbuhkan sikap belajar siswa yang lebih disiplin dan dapat membuat siiswa lebih aktif dan kreatif dalam belajar. Model pembelajaran project based learning juga memiliki potensi yang amat besar untuk membuat pengalaman belajar yang lebih menarik dan bermakna. Selain itu, project based learning juga memfasilitasi peserta didik untuk berinvestigasi, memecahkan masalah, bersifat students centered, dan menghasilkan produk nyata berupa hasil proyek.

Berdasarkan uraian diatas, peneliti melakukan sebuah penelitian yang berfokus pada penerapan model project based learning terhadap kemampuan pemecahan masalah matematika. Kemampuan pemecahan masalah matematika diterapkan berdasarkan apa yang menjadi sebuah permasalahan yang ada di lingkungan yang membutuhkan pemecahan dalam menyelesaikannya. Untuk itu, peneliti melakukan penelitian dengan judul "Penerapan Model Pembelajaran Project Based Learning Terhadap Kemampuan Pemecahan Masalah Matematika".

\section{TINJAUAN PUSTAKA}

\section{Kemampuan Pemecahan Masalah Matematika}

Matematika merupakan mata pelajaran yang sangat penting, yang dipelajari dari tingkat Sekolah Dasar sampai tingkat Perguruan tinggi. Matematika merupakan mata pelajaran yang membutuhkan logika dan penalaran serta sebagai dasar untuk pelajaran lainnya. Oleh karena itu matematika dikatakan sebagai Queen of Science.

Suriasumantri (Siagian, 2012: 125) menyatakan bahwa matematika pada garis besarnya merupakan pengetahuan yang disusun secara konsisten berdasarkan logika deduktif. Logika deduktif merupakan pola berfikir logika dari hal umum menuju hal khusus. Matematika dikenal sebagai ilmu deduktif karena proses mencari kebenaran dalam matematika berbeda dengan ilmu pengetahuan lainnya. Matematika merupkan akar dari berbagai ilmu pengetahuan dan menjadi cikal bakal untuk ilmu pengetahuan lain 
bermunculan, sehingga dapat dikatakan bahwa semua ilmu pengetahuan bersumber dari ilmu matematika. Nasution (2008: 40), menguasai matematika orang akan belajar mengatur jalan pikirannya dan sekaligus belajar menambah kepandaian. Dengan demikian, dapat dikatakan bahwa menguasai ilmu matematika berarti menguasai induk sebuah ilmu yang akan membuat pengetahuan seseorang bertambah dan mampu mengatur jalan pikirannya sendiri. Hal ini dapat membuat peserta didik dapat memecahkan masalah.

Membahas mengenai pemecahan masalah tidak terlepas dari apa itu masalah. Masalah tidak dapat dipisahkan dari kehidupan manusia, banyak cara yang dilakukan setiap manusia dalam memecahkan masalah. Pada hakikatnya masalah sering dianggap menjadi suatu beban dalam kehidupan, akan tetapi harus dijadikan sebagai cara memunculkan sesuatu yang baru dan menghasilkan perubahan yang lebih baik.

Masalah adalah suatu kendala atau persoalan yang harus dipecahkan. Dengan kata lain masalah merupakan kesenjangan antara kenyataan dan suatu yang diharapkan dengan baik agar tercapai tujuan dengan hasil yang maksimal. Masalah pada dasarnya merupakan suatu hambatan atau rintangan yang harus disingkirkan, atau pertanyaan yang harus dijawab atau dipecahkan. Hal ini juga diungkapkan oleh Sumiati (2009: 133) yang mengartikan masalah adalah kesenjangan antara kenyataan dan apa yang seharusnya. Situasi yang mencerminkan adanya kesenjangan itu disebut situasi yang problematis.

Masalah harus diselesaikan dan dipecahkan baik masalah dalam kehidupan sehari-hari, atau masalah peserta didik dalam pemecahan soal. Soal yang belum pernah dikerjakan peserta didik sebelumnya akan menjadi sebuah masalah sehingga membutuhkan waktu untuk menganalisa setiap kata kunci yang terdapat pada soal tersebut. Sebagaimana yang diungkapkan Suherman (2003:164) bahwa "soal tersebut akan merupakan masalah bagi seorang siswa sekolah menengah, bila siswa itu belum pernah menyelesaikan soal semacam itu. Masalah itu memerlukan penganalisaan dan setelah pola diketahui dapatlah diketemukan formulanya.Selanjutnya formula itu dibuktikan".

Hal ini senada juga yang diungkapkan oleh Siswono (2008: 62), mengatakan bahwa masalah matematika adalah soal matematika tidak rutin yang mencangkup aplikasi prosedur matematika yang sama atau mirip dengan hal yang sudah (baru saja) dipelajari di kelas. Dengan kata lain, masalah matematika merupakan soal matematika tidak rutin yang belum pernah didapatkan oleh peserta didik sewaktu belajar dikelas. Sehingga untuk menyelesaikannya, peserta didik perlu menganalisis permasalahan. Dengan menganalisis permasalahan yang ada pada soal akan banyak menunjang kreativitas peserta didik, yaitu kemampuan menciptakan ide baru baik yang bersifat asli ciptaannya sendiri, maupun merupakan modifikasi dari berbagai ide yang telah ada sebelumnya.

Polya (Sulistyowati, 2013:3) menyatakan bahwa ada empat langkah solusi untuk soal bertipe pemecahan masalah, yaitu: memahami masalah, merencanakan penyelesaian, menyelesaikan masalah sesuai dengan rencana dan melakukan pengecekan kembali terhadap semua langkah yang dikerjakan. Garofalo dan Lester (Suryadi, 2013: 1), pemecahan masalah mencangkup proses berfikir tingkat tinggi seperti proses visualisasi, asosiasi, abstraksi, manipulasi, penalaran, analisis, sintesis, dan generalisasi yang masingmasing perlu dikelola secara terkoordinasi. Maksud dari pendapat ini dapat diartikan bahwa keterampilan pemecahan masalah yang mengharuskan memiliki keterampilan berfikir tingkat tinggi dan kompleks yaitu melibatkan visualisasi, imajinasi, abstraksi dan asosiasi informasi yang diberikan. Oleh karena itu, penyelesaian masalah melalui proses belajar mengajar matematika dapat membantu peserta didik dalam meningkatkan dan mengembangkan kemampuan pada aspek penerapan, analisis, sintesis dan evaluasi. 
Pentingnya kemampuan pemecahan masalah, mengharuskan guru mengajarkan kepada peserta didik bagaimana cara pemecahan masalah yang baik pada semua tingkatan, sehingga peserta didik siap dalam menyelesaikan setiap soal yang diberikan tanpa takut tidak menemukan pemecahan masalah dari soal tersebut. Dalam pemecahan masalah, bukan hanya tujuan yang harus dicapai, tetapi tindakan apa yang harus dilakukan supaya masalah dapat diselesaikan. Tindakan tersebut masih harus ditemukan, dengan melakukan pengamatan yang teliti, sehingga memunculkan suatu pemahaman baru yang membawa ke pemecahan masalah.

Dengan demikian, pemecahan masalah matematika adalah proses berfikir tingkat tinggi dalam memahami masalah, merencanakan penyelesaian, menyelesaikan masalah sesuai dengan rencana dan melakukan pengecekan kembali terhadap semua langkah yang dikerjakan. Proses tersebut seperti proses visualisasi, asosiasi, abstraksi, manipulasi, penalaran, analisis, sintesis, dan generalisasi yang masing-masing perlu dikelola secara terkoordinasi, karena tidak mudah untuk mendapatkan pemecahan masalah. Terutama pemecahan masalah soal yang sering dihadapi peserta didik perlu latihan khusus yang diberikan oleh guru.

Kemampuan pemecahan masalah berarti kecakapan menerapkan pengetahuan yang sebelumnya kedalam situasi yang belum dikenal. Kemampuan seseorang dalam mengidentifikasi atau mengenal masalah, biasanya memecahkan masalah menggunakan cara yang berbeda-beda. Kemampuan ini banyak sekali difaktori oleh latar belakang akademis. Namun, tidak semua faktor yang disebutkan selalu menyebabkan seseorang mempunyai kemampuan dalam memecahkan masalah. Kemampuan pemecahan masalah muncul terutama jika yang bersangkutan terbiasa atau terlatih dalam menghadapi masalah.

Pemecahan masalah dalam matematika adalah penyelesaian dari situasi dalam matematika yang dianggap masalah bagi orang yang menyelesaikannya.Menurut Suherman (2003: 162), keterampilan memecahkan masalah harus dimiliki peserta didik. Keterampilan memecahkan masalah akan dimiliki oleh peserta didik apabila guru mengajarkan bagaimana memecahkan masalah yang efektif kepada peserta didiknya. Menurut Krajcik dan Blumenferld (Eggen, P dan Kauchak, D, 2012: 307) kemampuan pemecahan masalah bermula dari suatu masalah dan memecahkannya adalah fokus pembelajarannya. Fokus pembelajaran disini adalah cara untuk menjadikan masalah sebagai target pembelajaran yang harus segera dicari solusinya. Cara tersebut bertujuan agar para siswa memiliki pengalaman sebagaimana nantinya peserta didik menghadapi kehidupan professional.

Kemampuan pemecahan masalah banyak menunjang kreatifitas seseorang, yaitu kemampuan menciptakan ide baru,baik yang bersifat asli ciptaannya sendiri, maupun merupakan modifikasi dari berbagai ide yang telah ada sebelumnya, proses pemecahan masalah dapat berlangsung jika seseorang dihadapkan pada suatu persoalan yang didalamnya terdapat sejumlah kemungkinan jawaban. Kemampuan pemecahan masalah harus diajarkan kepada peserta didik, dengan cara pelatihan yang diberikan oleh guru. Pentingnya kemampuan pemecahan masalah oleh peserta didik dalam matematika ditegaskan juga oleh Branca (Jainuri, 2013: 2), yaitu: “(1) kemampuan menyelesaikan masalah merupakan tujuan umum pengajaran matematika; (2) penyelesaian masalah yang meliputi metode, prosedur dan strategi merupakan proses inti dan utama dalam kurikulum matematika; (3) penyelesaian masalah merupakan kemampuan dasar dalam belajar matematika".

Berdasarkan uraian tersebut dapat disimpulkan bahwa kemampuan pemecahan masalah matematika adalah kemampuan dalam mencari jalan keluar atas jawaban yang ingin dipecahkan, memerlukan jenis belajar yang lebih tinggi dan pemahaman obyeknya, 
serta kemampuan yang banyak menunjang kreatifitas seseorang. Kreatifitas tersebut adalah kemampuan menciptakan ide baru,baik yang bersifat asli ciptaannya sendiri, maupun merupakan modifikasi dari berbagai ide yang telah ada sebelumnya. Dimana kemampuan pemecahan masalah matematika merupakan kemampuan dasar yang harus dimiliki oleh setiap peserta didik.

\section{Model Pembelajaran Problem Based Learning}

Hasil belajar seseorang ditentukan oleh berbagai faktor yang mempengaruhinya. Salah satu faktor yang ada diluar peserta didik adalah guru profesional yang mampu mengelola pembelajaran dengan model pembelajaran yang tepat, yang memberi kemudahan bagi peserta didik untuk mempelajari materi pelajaran, sehingga menghasilkan belajar yang lebih baik lagi. Model pembelajaran merupakan cara yang diberikan guru dalam proses pembelajaran, dimana model pembelajaran ada bermacammacam yang dapat diterapkan pada saat mengajar peserta didik. Sutikno (2014: 34) mengatakan model pembelajaran adalah cara-cara menyajikan materi pelajaran yang dilakukan oleh pendidik agar terjadi proses belajar pada diri peserta didik dalam upaya mencapai tujuan. Keterampilan seorang guru memilih model pembelajaran yang baik merupakan faktor penting dalam proses pembelajaran. Pemilihan model pembelajaran yang digunakan oleh guru dalam setiap pertemuan kelas bukan dengan asal penerapan, melainkan setelah melalui seleksi yang berkesesuaian dengan perumusan tujuan pembelajaran.

Joyce (Ngalimun, 2013: 7) berpendapat model pembelajaran merupakan cara yang digunakan sebagai pedoman dalam merencanakan pembelajaran di kelas untuk menentukan perangkat-perangkat pembelajaran termasuk didalamnya buku-buku, kurikulum, dan lain-lain, dengan demikian dapat membantu peserta didik dalam mencapai tujuan pembelajaran. Hal ini serupa disampaikan Soekamto (Ngalimun, 2013: 8), model pembelajaran adalah kerangka konseptual yang melukiskan prosedur yang sistematis dalam mengorganisasikan pengalaman belajar untuk mencapai tujuan belajar tertentu dan fungsi sebagai pedoman bagi perancang pembelajaran dan para pengajar dalam merencanakan aktifitas belajar mengajar.

Berdasarkan beberapa pendapat diatas dapat disimpulkan bahwa model pembelajaran adalah langkah-langkah atau cara sebagai pedoman pembelajaran yang sistematis diterapkan oleh guru, untuk menentukan perangkat-perangkat pembelajaran yang menunjang aktivitas pembelajaran, agar peserta didik mencapai kompetensi yang diinginkan dan aktifitas belajar mengajar berjalan dengan baik.Perencanaan pembelajaran yang dilakukan oleh guru dalam menyajikan materi harus tepat sasaran. Selain dari perencanaan yang baik dan tepat guru perlu memiliki beragam model pembelajaran yang akan menunjang keberhasilan proses belajar peserta didik.

Salah satu model pembelajaran yang dapat meningkatkan kreativitas peserta didik dalam memecahkan masalah yaitu model pembelajaran problem based learning. Sani (2014: 172) mengatakan project based learning dapat didefinisikan sebagai sebuah pembelajaran dengan aktifitas jangka panjang yang melibatkan siswa dalam merancang, membuat dan menampilkan produk untuk mengatasi permasalahan dunia nyata. Dengan demikian model pembelajaran project based learning dapat digunakan sebagai sebuah model pembelajaran untuk mengembangkan kemampuan peserta didik dalam membuat perencanaan, berkomunikasi, menyelesaikan masalah dan membuat keputusan yang tepat dari masalah yang dihadapi. Menurut Kosasih (2014: 96) project based learning adalah model pembelajaran yang menggunakan proyek atau kegiatan sebagai tujuannnya. Pembelajaran difokuskan dalam pemecahan masalah yang menjadi tujuan utama dari proses belajar sehingga dapat memberikan pembelajaran yang lebih bermakna karena 
dalam belajar tidak hanya mengerti apa yang dipelajari tetapi membuat peserta didik menjadi tahu apa manfaat dari pembelajaran tersebut untuk lingkungan sekitarnya.

Pada hakikatnya model pembelajaran project based learning dirancang untuk digunakan pada permasalahan yang kompleks yang diperlukan pelajaran dalam melakukan investigasi dan memahaminya. Dengan mengkelompokkan peserta didik dalam memecahkan suatu proyek atau tugas maka akan melatih keterampilan peserta didik dalam merencanakan, mengorganisasi, negoisasi, dan membuat konsensus tentang isu-isu tugas yang akan dikerjakan, siapa yang bertanggung jawab untuk setiap tugas, dan bagaimana informasi akan dikumpulkan dan disajikan. Lebih lanjut Bie (Nglimun, 2013: 185) menegaskan project based learning yaitu: "model pembelajaran yang berfokus pada konsep-konsep dan prinsip-prinsip utama (central) dari suatu disiplin, melibatkan siswa dalam kegiatan pemecahan masalah dan tugas-tugas bermakna lainnya, memberikan peluang siswa bekerja secara otonom mengkonstruk belajar mereka sendiri, dan puncaknya menghasilkan produk karya siswa bernilai, dan realistik".

Dari berbagai pendapat para ahli diatas maka dapat disimpulkan project based learning adalah pembelajaran yang memerlukan jangka waktu panjang, menitikberatkan pada aktifitas peserta didik untuk dapat memahami suatu konsep atau prinsip dengan melakukan investigasi secara mendalam tentang suatu masalah dan mencari solusi yang relevan serta diimplementasikan dalam pengerjaan proyek, sehingga peserta didik mengalami proses pembelajaran yang bermakna dengan membangun pengetahuannya sendiri.Penekanan pembelajaran terletak pada aktifitas peserta didik untuk memecahkan masalah dengan menerapkan keterampilan meneliti, menganalisis, membuat, sampai dengan mempresentasikan produk pembelajaran berdasarkan pengalaman nyata. Metode pembelajaran project based learning memperkenankan peserta didik untuk dapat bekerja mandiri maupun dengan cara berkelompok dalam menghasilkan hasil proyeknya yang bersumber dari masalah kehidupan sehari-hari.

Buck Institute for Education (Hosnan, 2014: 321), dalam belajar project based learning memiliki beberapa karakteristik sebagai berikut: "(1) siswa mengambil keputusan sendiri dalam kerangka kerja yang telah ditentukan sebelumnya; (2) siswa berusaha memecahkan sebuah masalah atau tantangan yang tidak memiliki suatu jawaban yang pasti; (3) siswa ikut merancang proses yang akan ditempuh dalam mencari solusi; (4) siswa didorong untuk berfikir kritis, memecahkan masalah, berkolaborasi, serta mencoba berbagai macam bentuk komunikasi; (5) siswa bertanggung jawab mencari dan mengelola sendiri informasi yang mereka kumpulkan; (6) pakar-pakar dalam bidang yang berkaitan dengan proyek yang dijalankan sering diundang menjadi guru tamu dalam sesisesi tertentu untuk memberikan pencerahan bagi siswa; (7) evaluasi dilakukan secara terus-menerus selama proyek berlangsung; (8) siswa secara reguler mereflesikan dan merenungi apa yang telah mereka lakukan, baik secara proses maupun hasilnya; (9) produk dari akhir proyek (belum tentu berupa material, tetapi bisa berupa presentasi, drama, dan lain-lain) dipresentasikan didepan umum (maksudnya tidak hanya pada gurunya, namun bisa juga pada dewan guru, orang tua dan lain-lain) dan dievaluasi kualitasnya; (10) didalam kelas dikembangkan suasana penuh toleransi terhadap kesalahan dan perubahan, serta mendorong bermunculannya umpan balik serta revisi".

Adapun prinsip-prinsip project based learning menurut Thomas (Hosnan, 2014: 323) antaralain: (1) keputusan (centrality); (2) berfokus pada pertanyaan atau masalah; (3) investigasi konstruktif atau desain; (4) otonomi; (5) realisme. Selain itu ada pula tahapan project based learning yang dapat dilakukan menurut Sani (2014: 181) ada enam tahapan yaitu: (1) penyajian permasalahan; (2) membuat perencanaan; (3) menyusun penjadwalan; (4) memonitor pembuatan proyek; (5) melakukan penilaian; (6) evaluasi. 
Dari semua penjelasan diatas ada keunggulan penerapan model project based learning menurut Kurniasih (2014: 83) yaitu: “(1) meningkatkan motivasi belajar peserta didik untuk belajar mendorong kemampuan mereka untuk melakukan pekerjaan penting, dan mereka perlu dihargai; (2) meningkatkan kemampuan pemecahan masalah; (3) membuat peserta didik menjadi lebih aktif dan berhasil memecahkan problem-problem yang kompleks; (4) meningkatkan kolaborasi: (5) mendorong peserta didik untuk mengembangkan dan mempraktikkan keterampilan komunikasi; (6) meningkatkan keterampilan peserta didik dalam mengelola sumber; (7) memberikan pengalaman kepada peserta didik pembelajaran dan praktik dalam mengorganisasi proyek dan membuat alokasi waktu dan sumber-sumber lain seperti perlengkapan untuk menyelesaikan tugas; (8) menyediakan pengalaman belajar yang melibatkan peserta didik secara kompleks dan dirancang berkembang sesuai dunia nyata; (9) melibatkan para peserta didik untuk belajar mengambil informasi dan menunjukkan pengetahuan yang dimiliki, kemudian diimplementasikan dengan dunia nyata; (10) membuat suasana belajar menjadi menyenangkan, sehingga peserta didik maupun pendidik menikmati proses pembelajaran".

Disamping keunggulan project based learning adapula beberapa kelemahan project based learning menurut Sani (2014: 177) adalah "(1) membutuhkan banyak waktu untuk menyelesaikan masalah dan menghasilkan produk; (2) membutuhkan biaya yang cukup; (3) membutuhkan guru yang terampil dan mau belajar; (4) membutuhkan fasilitas, peralatan, dan bahan yang memadai; (5) tidak sesuai untuk siswa yang mudah menyerah dan tidak memiliki pengetahuan serta keterampilan yang dibutuhkan; (6) kesulitan melibatkan semua siswa dalam kerja kelompok".

\section{METODE}

Penelitian ini merupakan penelitian kuantitatif dengan metode eksperimen. Sugiyono (2008:107) bahwa "metode eksperimen dapat diartikan sebagai metode penelitian yang diinginkan untuk mencari pengaruh perlakuan tertentu terhadap yang lain melalui kondisi yang terkendali dan terkontrol". Pada pelaksanaanya penelitian melibatkan dua kelompok yaitu kelompok eksperimen yang diberi perlakuan dengan metode pembelajaran project based learning dan kelompok kontrol yang diberi perlakuan dengan model pembelajaran ekspositori.

Desain penelitian yang digunakan adalah posttest-only control group design. Desain penelitian yang peneliti gunakan adalah sebagai berikut:

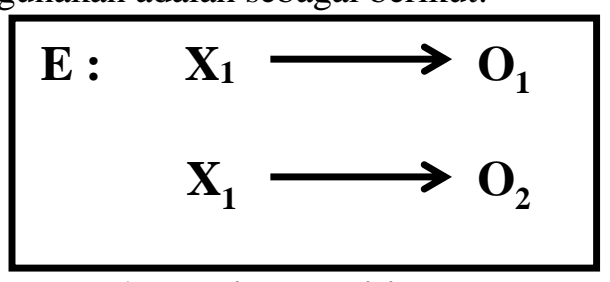

\section{Gambar 1. Desain Penelitian}

Penelitian ini dilakukan di salah satu SMK Swasta yang belokasi di Bekasi Timur pada tahun 2015 dengan jumlah populasi sebanyak 358 peserta didik. Berdasarkan jumlah populasi yang ada, maka ditentukan jumlah sampel sebanyak 70 peserta didik. Jumlah sampel yang di ambil sekitar $20 \%$ dari jumlah populasi. Teknik sampling yang digunakan adalah simple random sampling dimana setiap populasi memiliki kesempatan yang sama untuk menjadi sampel. Pemilihan sampel dilakukan dengan pengocokan dan pengundian. 
Pada penelitian ini terdapat dua variabel diataranya variabel bebas yaitu model peembelajaran problem based learning dan variabel terikat yaitu kemampuan pemecahan masalah matematika. Prosedur penelitian ini dilakukan dengan memberikan perlakuan berbeda pada dua kelompok. Pada kelompok pertama, peserta didik diajarkan menggunakan model pembelajaran problem based learning dan pada kelompok kedua, peserta didik diajarkan menggunakan model pembelajaran ekspositori. Setelah memberikan perlakuan selama satu bulan, maka pengambilan data dilakukan dengan memberikan masing-masing sampel tes essai sebanyak 10 butir soal yang valid.

\section{HASIL DAN PEMBAHASAN}

\section{Hasil Penelitian}

Pada penelitian ini dilakukan tiga pengujian, diantara nya yaitu uji deskriptif data, uji prasyarat analisis data dan uji analisis data. Uji desriptif data yang dilakukan antara lain yaitu menghitung mean, median, modus, varians dan simpangan baku. Untuk uji prasyarat analisis data yang dilakukan yaitu uji normalitas dan homogenitas. Uji analisis data dilakukan dengan uji t.

1. Uji Deskriptif Data

Hasil perhitungan deskriptif data yang dihitung menggunakan Microsoft Exel 2007 adalah sebagai berikut :

Tabel 1. Uji Deskriptif Data

\begin{tabular}{lll}
\hline & Kelas Eksperimen & Kelas Kontrol \\
\hline Mean & 85,19 & 77,93 \\
Median & 85,14 & 78,25 \\
Modus & 84,7 & 79,3 \\
Varians & 52,46 & 51,43 \\
Simpangan Baku & 7,24 & 7,17 \\
\hline
\end{tabular}

2. Uji Prasyarat Analisis Data

a. Uji Normalitas

Hasil perhitungan normalitas yang dihitung menggunakan Microsoft Exel 2007 adalah sebagai berikut :

Tabel 2. Uji Normalitas

\begin{tabular}{llll}
\hline & $\mathbf{X}^{\mathbf{2}}$ Hitung & $\mathbf{X}^{\mathbf{2}}$ Tabel & Keterangan \\
\hline Eksperimen & 2,67 & 11,070 & Berdistribusi Normal \\
Kontrol & 0,75 & 12,592 & Berdistribusi Normal \\
\hline
\end{tabular}

b. Uji Homogenitas

Hasil perhitungan homogenitas yang dihitung menggunakan Microsoft Exel 2007 adalah sebagai berikut :

Tabel 3. Uji Homogenitas

\begin{tabular}{lll}
\hline F hitung & F tabel & Keterangan \\
\hline 1,02 & 1,776 & Homogen \\
\hline
\end{tabular}

3. Uji Analisis Data

Hasil perhitungan uji t yang dihitung menggunakan Microsoft Exel 2007 adalah sebagai berikut :

Tabel 4. Uji Analisis Data

\begin{tabular}{lll}
\hline t hitung & t tabel & Keterangan \\
\hline 3,87 & 1,67 & H0 ditolak \\
\hline
\end{tabular}


Berdasarkan tabel di atas dapat diketahui bahwa nilai $\mathrm{t}$ hitung $<\mathrm{t}$ tabel. Ini berarti bahwa H0 ditolak dan H1 diterima, sehingga dapat disimpulkan terdapat pengaruh penggunaan model pembelajaran project based learning terhadap kemampuan pemecahan masalah matematika.

\section{Pembahasan}

Berdasarkan hasil penelitian, dapat diketahui bahwa penggunaan model pembelajaran project based learning memiliki pengaruh terhadap kemampuan pemecahan masalah matematika peserta didik. Dari deskripsi data yang diperoleh bahwa nilai kemampuan pemecahan masalah matematika peserta didik kelas eksperimen dari 35 peserta didik memiliki rata-rata 85,19 . Nilai kemampuan pemecahan masalah matematika kelas kontrol dari 35 peserta didik memiliki rata-rata 77,93. Dari hasil perhitungan penelitian ini dapat dikatakan bahwa nilai rata-rata kemampuan pemecahan masalah matematika peserta didik kelas eksperimen lebih tinggi daripada nilai rata-rata kemampuan pemecahan masalah matematika peserta didik kelas kontrol.

Hasil pengolahan analisis data menunjukkan keterangan bahwa terdapat pengaruh penerapan model pembelajaran Project based learning terhadap kemampuan pemecahan masalah matematika. Hal ini juga dapat dilihat dari proses pembelajaran maupun dari lembar penilaian sikap dan keterampilan individu peserta didik yang cenderung baik, karena peserta didik secara aktif mengikuti semua rangkaian kegiatan proses pembelajaran secara aktif dan antusias baik secara kelompok maupun individu. Dan peserta didik menjadi lebih berani berinteraksi dengan guru maupun kepada temannya.

Berdasarkan wawancara peserta didik dikelas, ternyata pengalaman masa lalu membuat perubahan sikap dalam menerima pelajaran dikelas. Pada saat itu mereka mendapatkan suasana belajar yang menegangkan dan mereka takut dalam bertanya ketika mereka mengalami kesulitan. Dalam pertemuan pertama, suasana belajar menegangkan karena masih mengikuti pengalaman yang lalu dan proses belajar menjadi pasif dan tidak efektif dalam penerimaan pembelajaran.

Pelaksanaan pembelajaran project based learning ini dengan membagi peserta didik kedalam kelompok kecil yang terdiri dari 6-7 orang. Kelompok tersebut bersifat permanen, artinya selama proses pembelajaran berlangsung peserta didik tetap pada kelompok kecilnya. Peserta didik secara berkelompok diberikan tugas proyek yang mengambil data dari lingkungan sekolah. Peserta didik dipacu menggunakan pengetahuannya yang sudah dimiliki untuk mencari solusi dari permasalahan yang ada dilingkungan sekolah. Guru hanya memfasilitasi dan mengawasi jalannya proses pembelajaran. Pembelajaran ini diakhiri dengan mengadakan presentasi terhadap hasil kerja tugas proyek yang dikerjakan peserta didik. Peserta didik lebih semangat belajar matematika dan lebih aktif dalam mengikuti pembelajaran. Dengan demikian, pembelajaran project based learning ini secara tidak langsung dapat menumbuhkan minat dan motivasi belajar peserta didik. Dampak dari pembelajaran seperti ini membuat peserta didik yang tidak suka matematika menjadi suka dan lebih leluasa dalam bertanya. Dengan demikian, dampak dari model pembelajaran project based learning telah dirasakan peserta didik karena peserta didik merasa bersama-sama dalam menghadapi suatu masalah, saling bertukar pengetahuan, dan juga saling melengkapi, sehingga membuat hasil pembelajaran meningkat lebih baik. Pernyataan tersebut diperkuat oleh Kurniasih (2014: 83) yaitu: “(1) meningkatkan motivasi belajar peserta didik untuk belajar mendorong kemampuan mereka untuk melakukan pekerjaan penting, dan mereka perlu dihargai; (2) meningkatkan kemampuan pemecahan masalah; (3) membuat peserta didik menjadi lebih aktif dan berhasil memecahkan problem-problem yang kompleks; (4) 
meningkatkan kolaborasi: (5) mendorong peserta didik untuk mengembangkan dan mempraktikkan keterampilan komunikasi; (6) meningkatkan keterampilan peserta didik dalam mengelola sumber; (7) memberikan pengalaman kepada peserta didik pembelajaran dan praktik dalam mengorganisasi proyek dan membuat alokasi waktu dan sumber-sumber lain seperti perlengkapan untuk menyelesaikan tugas; (8) menyediakan pengalaman belajar yang melibatkan peserta didik secara kompleks dan dirancang berkembang sesuai dunia nyata; (9) melibatkan para peserta didik untuk belajar mengambil informasi dan menunjukkan pengetahuan yang dimiliki, kemudian diimplementasikan dengan dunia nyata; (10) membuat suasana belajar menjadi menyenangkan, sehingga peserta didik maupun pendidik menikmati proses pembelajaran".

Hasil tersebut menguatkan dari penelitian sebelumnya yang dilakukan oleh Putriari (2013: 5) bahwa adanya peningkatan kemampuan pemecahan masalah dengan model project based learning. Hal ini terbukti dengan keefektifan peserta didik dalam mengerjakan permasalahan yang dikerjakan dengan anggota kelompok dan meningkatkan kemandirian dalam berfikir menganalisis permasalahan, sehingga mampu menyelesaikan masalah.

Proses pembelajaran matematika dengan mengguanakan model project based learning dalam implementasinya perlu dilakukan pembuatan perencanaan pembelajaran yang baik. Guru harus memperhatikan psikis dan kesiapan belajar matematika. guru harus mencari tahu apa yang terjadi sebelumnya dari mereka, sehingga kekurangan dari pengalaman masa lalunya tertutupi oleh gaya belajar yang menyenangkan. Dengan demikian, tujuan penggunaan model pembelajaran dapat terselesaikan dengan baik.Ini diperkuat oleh Siswanto (2012: 56) yang menyatakan salah satu faktor yang mempengaruhi belajar yaitu kesiapan. Kesiapan adalah kesediaan untuk memberi respon, sehingga harus diperhatikan dalam proses belajar. Dengan adanya kesiapan belajar, hasil yang dicapai baik.

Berbeda dengan model pembelajaran problem based learning, model pembelajaran ekspositori cenderung monoton karena peserta didik lebih bersikap pasif dan hanya menunggu materi yang diberikan oleh guru. Model ekspositori ini lebih terpaku dari apa yang disampaikan guru. Peserta didik hanya mendengar, mencatat, dan menjawab soal yang diberikan walaupun dibentuk dalam kelompok kecil. Sikap yang ditimbulkan peserta didik ketika proses pembelajaran menggunakan ekspositori kurang memacu kreatifitas peserta didik dalam memecahkan masalah yang diberikan. Peserta didik kurang leluasa mengeluarkan pendapat dan hanya terpaku dengan apa yang sudah mereka terima. Sikap ini sangat terlihat ketika proses pembelajaran berlangsung.

Dengan pembelajaran ekspositori, peserta didik tidak belajar sesuai dengan gaya belajarnya masing-masing, tetapi mereka hanya mengikuti arahan. Penyelesaian materi juga disesuaikan dengan alokasi yang direncanakan. Ini diperkuat oleh Hamzah dan Muhlisrarini (2014: 274) bahwa pembelajaran ekspositori memiliki kelemahan, yaitu: (1) kecenderungan guru yang berperan dalam proses pembelajaran; (2) siswa enggan mengemukakan pendapat atau bertanya ketika selesai penyajian; (3) siswa malu maju ke muka ketika diminta untuk menyelesaikan soal dipapan tulis. Berdasarkan pembahasan diatas, dapat disimpulkan bahwa terdapat pengaruh penerapan model pembelajaran Project based learning terhadap kemampuan pemecahan masalah matematika. Kemampuan pemecahan masalah matematika yang diajarkan menggunakan model pembelajaran problem based learning lebih baik daripada yang diajarkan dengan menggunakan model pembelajaran ekspositori. 


\section{PENUTUP}

\section{Simpulan}

Terdapat pengaruh penerapan model pembelajaran Project based learning terhadap kemampuan pemecahan masalah matematika. Kemampuan pemecahan masalah matematika yang diajarkan menggunakan model pembelajaran problem based learning lebih baik daripada yang diajarkan dengan menggunakan model pembelajaran ekspositori.

\section{Saran}

1. Model pembelajaran project based learning hendaknya dijadikan alternatif dalam menyampaikan pelajaran matematika karena memberikan pengaruh positif terhadap kemampuan pemecahan masalah matematika.

2. Hendaknya guru matematika mencoba berbagai macam variasi atau metode dalam penyampaian materi pelajaran agar peserta didik tidak jenuh atau bosan dalam menerima pelajaran matematika.

3. Hendaknya guru matematika perlu memperhatikan bahwa keberhasilan pendidikan matematika tidak sepenuhnya dipengaruhi oleh intelegensi seseorang melainkan ada faktor lain yang salah satunya adalah penggunaan metode belajar.

4. Hedaknya orang tua lebih meningkatkan perhatian kepada anak khususnya kepada pendidikan anak, karena demikan akan mendorong peningkatan prestasi belajar di sekolah.

5. Hendaknya guru dan orang tua menggali terus potensi yang dimiliki oleh anak dan diarahkan kearah yang lebih baik.

\section{DAFTAR PUSTAKA}

Amaliah. 2012. Evaluasi Pembelajaran. Jakarta: Unindra Press.

Eggen, P \&Kauchak, D. 2012. Strategi dan Model Pembelajaran. Jakarta: Indeks.

Hamzah dan Muhlisrarini. 2014. Perencanaan dan Strategi Pembelajaran

Matematika. Depok: Raja GrafindoPersada.

Hosnan. 2014. Pendekatan Saintifik Dan Kontekstual Dalam Pembelajaran Abad 21.

Jakarta: Ghalia Indonesia.

Jainuri. 2013. Pemecahan Masalah Matematika.

http://panduanguru.com/pemecahan_masalah_matematika, diakses pada 12

Februari 2015.

Kosasih. 2014. Strategi Belajar Dan Pembelajaran. Bandung: Yarma Widya.

Kurniasih. 2014. Sukses Mengimplementasikan Kurikulum 2013. Jakarta: Kata Pena.

Nasution, A. H. 2008. Landasan Matematika. Jakarta: Bhatara Karya Aksara.

Ngalimun. 2013. Strategi Dan Model Pembelajaran. Yogyakarta: AswajaPresindo

Putriari, Marinda Ditya. 2013. Keefektifan Project Based Learning Pada Pencapaian

Kemampuan Pemecahan Masalah Peserta Didik Kelas X SMK Materi Program Linear. Skripsi. http://lib.unnes.ac.id18796/4101409015.pdf, diakses pada 14 Februari 2015.

Sani, Ridwan Abdullah. 2014. Pembelajaran Saintifik. Jakarta: Bumi Aksara.

Siagian, Roida. 2012. Pengaruh minat dan kebiasaan belajar peserta didik terhadap prestasi belajar matematika. Jurnal Formatif, Vol. 2 No.2: 125.

Siswono, T. Y. E. 2008. Proses berfikir kreatif peserta didik dalam memecahkan dan mengajukan masalah matematika. Jurnal Formatif, Vol. 15 No. 1: 62.

Siswanto. 2012. Pengaruh model pembelajaran problem based learning (PBL) terhadap kemampuan pemecahan masalah dan hasil belajar kognitif biologi siswa kelas vii Smp Negeri 14 Surakarta. Jurnal Pendidikan Biologi, Vol. 4. 
No. 2. http://jurnal.fkip.uns.ac.id/index.php/bio/article/viewFile/1416/977, diakses pada 13 Januari 2015.

Sugiyono. 2008. Metode Penelitian Pendidikan Kuantitatif, Kualitatif, Dan R\&D. Bandung: Alfabeta.

Suherman, E. 2003. Strategi Pembelajaran Matematika Kontenporer: Common Text Book Edisi Revisi. Bandung: FTMIPA UPI.

Sulistyowati. 2013. Meningkatkan Kemampuan Pemecahan Masalah Matematika

Melalui Model Problem Based Learning (PBL).

http://respository.uny.edu/6615/4/s_mtk_0805582_chapterl.pdf, diakses pada 01 Januari 2015.

Sumiati, dan Asra. 2009. Metode Pembelajaran. Bandung: Wancana Prima.

Sutikno. 2014. Metode dan Model-Model Pembelajaran. Lombok: Holistica.

Suryadi, Didi. 2013. Pemecahan Masalah Matematika. http://didisuryadi.staf.upi.edu/6342/4/Bab-4-Pemecahan-Masalah-Matematika.pdf, diakses pada 01 Januari 2015. 